\title{
CHANGES IN INDUSTRIAL DISTRICTS DEVELOPMENT IN CONDITIONS OF KNOWLEDGE SPILLOVERS (ITALIAN CASE)
}

This article is devoted to the searching the factors of the industrial districts success and synergy under the conditions of the new paradigm of the socio-economic system development for using in Russia. In accordance with this goal, new changes in the theory and practice of the industrial districts development are considered. On the example of the Italian scientific school, the stages of the evolution of the theory of "industrial districts" in foreign science and development of the traditional approach are determined. The article is focused on the geoeconomic paradigm and the concept of «localized knowledge spillovers» as new discussion fields where innovations and space are united. Both changes in the Italian economy and industrial districts are shown. The new factors of its successful development are determined.

Keywords: industrial districts (ID), ID-theory, "Third Italy", spatial innovative development, local structures, geo-economical paradigm, localized knowledge spillovers (LKS - concept).

\section{Introduction}

Industrial districts/clusters (IDs) are widespread in many different countries. Despite the lack of theoretical understanding, the world practice has already accumulated considerable experience in the operation of local industrial structures (industrial districts): Manchester (UK); NIC region of South-East Asia; Sheffield (manufacture of cutlery), Birmingham (metal products). Also, they are becoming more important in globalization. A variety of circumstances provokes the interest to the research of IDs:

${ }^{1}$ @ C Frolova E. D., Frolova E. A. Text. 2014.
- the success of well-known districts/clusters Silicon Valley and Route 128;

- the forming of regional innovative system;

- the complex relationship between local networks (SMEs) and global networks (subsidiaries of the multinational corporations);

- the problem of the small countries competitiveness;

and, at least, the issue how regional space can be a place of synergy.

The goal of the article is to search the factors of the industrial districts success and synergy under the conditions of the new paradigm of the socio-economic system development for using in Russia. The most advanced results in the research of the current issue (in practice and theory) refer 
to Italy that has represented to the world the economic phenomenon of the "Third Italy" (the most famous region was Emilia-Romagna). They have always been successful, but their experience and possibility to apply this experience to the Russian reality has been underestimated. Russian scientific regional school is well-known in the world. But it is very important for Russia and Russian regions to know the conditions of IDs formation and successful operations in order to create effective domestic operators that are competitive in the global economic space especially in the context of a knowledge economy.

\section{The theoretical basis of industrial districts}

The foreign and native theoretical base of research in industrial districts is very broad and requires a certain variety of approaches to their definition. In accordance with those approaches, scientists formulate IDs as a "geographical concentrations of firms in the same or similar industries", "localized industries", "agglomeration of small and medium-sized enterprises" [1, 2, 3, 28, 33, 34]. The beginning of the industrial districts theory development refers to the founder of the theory of "industrial districts" A. Marshall (British School). Then A. Markusen identified different types of

Table 1

Main stages of the industrial districts theory development (on the example of the Italian scientific school) $[1,2,3,33,34]$

\begin{tabular}{|c|c|c|}
\hline Stages & The essence and scientists & Additional information \\
\hline Stage 1 & $\begin{array}{l}\text { Borrowing term «industrial district, region, } \\
\text { agglomeration», famous Italian scientist G. } \\
\text { Becattini (classic Italian school) developed } \\
\text { his theory of the Italian industrial districts. } \\
\text { Ideas of G. Becattini and Marshall are } \\
\text { similar, but fundamentally distinguished by } \\
\text { the presence of two key concepts: «external } \\
\text { economy» and «agglomeration economy» }\end{array}$ & $\begin{array}{l}\text { He also develops the concept of «industrial atmosphere», brings } \\
\text { to the first place «socio-economic component» and «territorial } \\
\text { peculiarities» and based on these economic results. } \\
\text { He defines «industrial districts» as «companies concentrated on a } \\
\text { limited area and embedded in the social environment of the area, } \\
\text { which is bounded by natural and historical reasons» }\end{array}$ \\
\hline Stage 2 & $\begin{array}{l}\text { Italian concept of «industrial districts» is } \\
\text { called «Marshallian industrial district». } \\
\text { G. Becattini introduces the term } \\
\text { «districtualization» (the process that } \\
\text { describes the emergence of districts within } \\
\text { local economies) }\end{array}$ & $\begin{array}{l}\text { This process was studied by many researches. For example, Belussi } \\
\text { describes the process of «districtualization» as the following: slow } \\
\text { accumulation of tacit knowledge and practical knowledge within } \\
\text { the founder firm of the district, then local enlargement of inter-firm } \\
\text { division of labour and firm specialization, then continuous process of } \\
\text { task externalization, firm decentralization and creation of spin-off }\end{array}$ \\
\hline Stage 3 & $\begin{array}{l}\text { Further developing the theory of industrial } \\
\text { districts Italian scientists provided two } \\
\text { forms of closed local systems. Valuable } \\
\text { for theories are considered not only the } \\
\text { proposed definition of «industrial district», } \\
\text { but also the conceptual basis of their } \\
\text { operation, especially in the context of the } \\
\text { interaction of a «global» and «local» }\end{array}$ & $\begin{array}{l}\text { The first is «Industrial district» as a local system organized around } \\
\text { one or more large companies successful producing goods/services } \\
\text { on a limited area. The second form is «industrial district». It } \\
\text { can be considered as a combination of a certain number of } \\
\text { «open teams» consisting of autonomous small or medium-sized } \\
\text { companies taking their particular place in the local economy }\end{array}$ \\
\hline Stage 4 & $\begin{array}{l}\text { Analysing development and diversity } \\
\text { emerged in the Italian industrial districts } \\
\text { E. Markusen (American School) introduced } \\
\text { the concept of «attracting seats» in addition } \\
\text { to Marshall new industrial districts }\end{array}$ & $\begin{array}{l}\text { Also they identify five types of «industrial districts»: satellite } \\
\text { platform district; state anchored district; mixed district; special } \\
\text { technological area and the area of the type « hub-and-spoke } \\
\text { district» }\end{array}$ \\
\hline Stage 5 & $\begin{array}{l}\text { At this stage of the research of the } \\
\text { phenomenon «industrial districts «G. } \\
\text { Becattini together with the followers } \\
\text { (Marco Bellande and L.De Propris) focused } \\
\text { on criticizing of the ignoring of the local } \\
\text { peculiarities. Researchers are trying to } \\
\text { answers the important question: how } \\
\text { industrial districts should «respond» to } \\
\text { changes in the globalized economy? }\end{array}$ & $\begin{array}{l}\text { The answers are based on the following theoretical platform }[1,3] \text { : } \\
\text { - globalization, international networks have unforeseen factors } \\
\text { that can hinder the development of the economy and the } \\
\text { introduction of innovations; } \\
\text { - there are two major trends that determine the dynamics and } \\
\text { efficiency of district development: innovative scientific knowledge } \\
\text { (1) and the development of global international networks } \\
\text { (2). In these circumstances keys to successful development of } \\
\text { industrial districts are the following: management of industrial } \\
\text { companies integrated into the local economy; the centralization } \\
\text { and decentralization of strategic planning; changing trend of } \\
\text { industrial agglomeration methods; } \\
\text { - only those regions that have a strong socio-cultural ties and } \\
\text { deep-rooted customs and traditions, will be able to keep their } \\
\text { «identity» facing globalization }\end{array}$ \\
\hline
\end{tabular}


sticky places in slippery space. But more excellent results were achieved by the Italian school of industrial districts.

We have already investigated the foreign (on the example of the Italian scientific school) experience in the field of industrial districts and divided scientific research into some phases $[14,15]$ so now we can easily add some new elements into those stages (table 1). For example, the Marshall's concept based on the importance of external economies. As for Italian scientific school «special attention is paid to the role of IDs as socio-economic entities» [30, p. 475].

The main peculiarity of the current stage of the IDs-theory is a spatial factor of socio-economical system development. Russian scientists (for example A. Tatarkin [34]) as a pioneer has begun to investigate this aspect of the industrial region development.

But the significant contribution to the theory of industrial districts is made by the geo-economic paradigm. Geo-economical approach to researching of world economy gives us some new basic attributes and categories. It considers IDs as a «local structures» in the global space and significantly expands the essence of the concept "industrial districts" and set parameters for their evaluation (measurement).

\section{"Industrial district" as a local structure in the global geoeconomical space}

As the previous paradigm is unable to explain many modern spatial processes, emerging a need to build a new theory based on the new methodology. This theory is related to the geo-economic paradigm which defines natural economic areas as the point of global growth.

We want to emphasize that the global geo-economics school was founded by the Italian $\mathrm{M}$. Parmelee [29]. He first moved away from the linear paradigm and considered a district as a space, formulated the idea of economic borders of functioning of an enterprise, district and raised the problem of providing the geo-economic competition. The modern concept of the spatial development is presented by Jean Carlo and Paolo Savona [17]. The geo-economic paradigm highlights such factors as absolutely new information flows, flows of administrative decisions, the mobility of the economic system, the global network where a rapid transfer of wealth takes place.

In order to capture the essence of the "industrial district" at the present stage of globalization, it is necessary to use the new (geo-economical) system of terms. For example, we can see obliteration of the border between the inner and outer spheres of activity; it is necessary to consider, to regard external ties not only as ones according to our country, but also in relating to any other areas, that are forming by internationalized reproduction chains etc. [16]. Thus, we determine the local structure "industrial district" as an area of strategic activities with economic borders (not geographical borders) which includes many particular links of international reproductive cycles and focus on the borders of operating (regions/countries) rather than type of the processes.

It is possible to identify factors that allow "industrial district" to perform as a point of global growth:

- the significant level of high-tech equipment and special innovation environment;

- the high degree of involvement of small and medium-sized enterprises;

- the high degree of specialization in the production of certain products focused on the global business projects;

- the evident social component of business.

So, we have figured out that the analysis needs new indicators such as the flow of information, the speed of the movement of finance in global networks. However, this (the geo-economic paradigm) is not enough today. In modern conditions there must be a new methodology. The scientific community has formulated it as «Knowledge Spillovers» [32].

\section{Knowledge spillovers as a new methodological platform}

First, the concept of «Knowledge Spillovers» (KS) was stated in the EU-project [28, p. 36] (table 2). It was presented as a new theoretical basis and for the functioning and development of IDs.

Surely, the knowledge paradigm is fundamentally changing the view on the region. For example,

Table 2

Development of ID-theories [28, p. 36]

\begin{tabular}{|l|l|}
\hline \multicolumn{1}{|c|}{ Base theory } & \multicolumn{1}{c|}{ Developments } \\
\hline Location Theory & $\begin{array}{l}\text { New Economic Geography } \\
\text { Increasing Returns }\end{array}$ \\
\hline $\begin{array}{l}\text { Industrial District } \\
\text { Theory }\end{array}$ & $\begin{array}{l}\text { Flexible Production } \\
\text { Social Values Conducive to } \\
\text { spillovers }\end{array}$ \\
\hline $\begin{array}{l}\text { Transaction Costs and } \\
\text { Institutional Theory }\end{array}$ & $\begin{array}{l}\text { Organizational Theories } \\
\text { Sociological Theories of } \\
\text { Embeddness }\end{array}$ \\
\hline $\begin{array}{l}\text { International Business } \\
\text { Theory }\end{array}$ & $\begin{array}{l}\text { Innovation and Learning } \\
\text { Institutional Drivers } \\
\text { DFI (Direct Foreign Investment) }\end{array}$ \\
\hline Regional Studies & $\begin{array}{l}\text { Knowledge Spillovers } \\
\text { Local spiral of knowledge }\end{array}$ \\
\hline
\end{tabular}


earlier the paradigm of the concentration and specialization of industries and sectors was predominated. New means of the accumulation of knowledge and telecommunication networks break into a linear chain and create a corpuscular (a modular) system. The location of industries and economic assets occur not on the technological principle but intellectual one.

The study of innovations in the space is associated with the rediscovery (reconsideration) of the concept "district". Today, the region is the object of interest not as a municipality but as a spatial innovation system, a network cluster of economic entities, «localized knowledge spillovers» (LKS) [32].

However, a new knowledge concept of the region has more problems than findings. The concept «localized knowledge spillovers» (LKS- concept) is the most criticized. It is most fully represented in the works of S. Breschi and F. Lissoni [32, p. 133]. The idea of the concept is that for companies operating in the vicinity of the source of knowledge, it is easier and faster to innovate than to revive firms located elsewhere. The authors recognize that knowledge flows are agglomerating force but question the strategy of uniting all flows under one "roof" of LKS [ 32, p.156].

According to the knowledge economy concept the modern district is characterized as follows:

- there is a balance of cooperation and competition of its subjects;

- within the region between its subjects intangible communication (information, financial, etc.) dominates;

- the boundaries between firms are leveled;

- the boundaries of the district labor market are revised;

- the migration of knowledge takes place.

How to characterize and measure the development of the district under these conditions? In the old paradigm the exclusive characteristic of the Italian economy was the rich north and the poor south. But in modern conditions there is a definite shift because originating in the north knowledge flows towards the south (the number of patents per person is confirmed).

\section{Economy of Italy: positive changes and the problems}

In spite of the difficulties of the world economy in the contemporary epoch, nevertheless, the country demonstrates some development results (table 3).

Till 2007 the Italian economy always had a positive growth (GDP growth $-2.2 \%$ in 2006, $1.7 \%$ in 2007), during the recession and crisis period
Table 3

Some facts about economy of Italy: current situation (on the base of traditional approach)

\begin{tabular}{|c|c|}
\hline Population (2012) & 60.92 million [31] \\
\hline Industries (author) & $\begin{array}{l}\text { Tourism, machinery, iron and } \\
\text { steel, chemicals, motor vehicles, } \\
\text { food processing, ceramics, textiles, } \\
\text { clothing, footwear }\end{array}$ \\
\hline \multirow{3}{*}{$\begin{array}{l}\text { Gross Domestic } \\
\text { Product (GDP) - } \\
\text { composition [24] }\end{array}$} & Agriculture $-2 \%$ \\
\hline & Industry $-24.4 \%$ \\
\hline & Services $-73.5 \%$ (2013 est.) \\
\hline GDP Growth Rate & $\begin{array}{l}2.5 \% \text { (2012) [24], -1.8 \% (IMF est. } \\
2013 \text { ); } 0.7 \% \text { (World Bank est. 2013), } \\
0.7 \% \text { (IMF est. 2014) [9] }\end{array}$ \\
\hline Export/Import & $\begin{array}{l}\text { Export remains almost the same } \\
\text { compared with 2012, while imports } \\
\text { decreased by } 4.8 \% \text {. Export was } \\
\text { positive towards non-EU countries } \\
\text { and negative towards EU countries } \\
(2013) \text { [13] }\end{array}$ \\
\hline $\begin{array}{l}\text { Largest Companies } \\
\text { (author) }\end{array}$ & $\begin{array}{l}\text { Energy sector: ENI, ENEL; } \\
\text { Investment, Finance and } \\
\text { Banks: Exor, UniCredit Group; } \\
\text { Assicurazioni Generali, Intesa } \\
\text { SanPaolo, Poste italiane; } \\
\text { Automotive: Fiat Group, Ferrari; } \\
\text { Other Industries: Prysmian, Pirelli, } \\
\text { Marazzi, Prada }\end{array}$ \\
\hline FDI & $\begin{array}{l}\text { Outward FDI } € 365 \text { billion, inward } \\
\text { FDI } € 248 \text { billion (2010) [18] }\end{array}$ \\
\hline Inflation rate & $3.3 \%(2012), 2013: 1.3 \%(2013)[20]$ \\
\hline $\begin{array}{l}\text { Unemployment } \\
\text { rate }\end{array}$ & $10.7 \%(2012)[36]$ \\
\hline
\end{tabular}

Table 4

Gross Domestic Product Growth of EU-countries, \% (by IMF) [7]

\begin{tabular}{|l|c|c|c|c|}
\hline GDP Growth & $\mathbf{2 0 1 1}$ & $\mathbf{2 0 1 2}$ & $\mathbf{2 0 1 3}$ & $\mathbf{2 0 1 4}$ (est) \\
\hline Germany & 3.01 & 0.09 & 0.03 & 1.03 \\
\hline France & 2.0 & 0.0 & -0.2 & 0.8 \\
\hline Italy & 0.4 & -2.4 & -1.8 & 0.7 \\
\hline Spain & 0.4 & -1.4 & -1.6 & 0.0 \\
\hline
\end{tabular}

the GDP growth dropped dramatically. The Italian economy is still not recovered, but in the beginning of 2014 the positive trend is marked (table 4).

Anyway it is difficult to make any forecast about the next months and the year 2014 as a total. The following tables represent the trend of the GDP growth of four countries of EU (table 4) and of ten developed countries. (table 5).

Talking about the perspective we can underline some positive changes: Italy ranks as the 9th economy in the world; Italy is one of the six founders of European Union; Italy is a member of the G-8 group of countries; Universal Exposition 
Gross domestic product, millions of US dollars, 2012 [5]

\begin{tabular}{|c|c|c|c|c|c|}
\hline Ranking & Country & GDP & Ranking & Economy & GDP \\
\hline 1 & United States & $16,244,600$ & 6 & United Kingdom & $2,471,784$ \\
\hline 2 & China & $8,227,103$ & 7 & Brazil & $2,252,664$ \\
\hline 3 & Japan & $5,959,718$ & 8 & Russian Federation & $2,014,775$ \\
\hline 4 & Germany & $3,428,131$ & 9 & Italy & $2,014,670$ \\
\hline 5 & France & $2,612,878$ & 10 & India & $1,841,710$ \\
\hline
\end{tabular}

Table 6

Italian main trading partners (millions of euro) $[15,21]$

\begin{tabular}{|l|c|l|c|}
\hline \multicolumn{2}{|c|}{ Countries to which Italy exports (2012) } & \multicolumn{2}{c|}{ Countries from which Italy imports (2012) } \\
\hline Germany & 48,713 & Germany & 55,219 \\
\hline France & 43,169 & France & 24,318 \\
\hline United States & 26,656 & China & 20,385 \\
\hline Switzeland & 22,878 & Netherland & 18,331 \\
\hline United Kindom & 18,964 & Russia & $\begin{array}{l}\text { Import: Mining and quarrying products, Chemical products, } \\
\text { Basic metals, Transport equipment, Textiles, Food\&Tobacoo. }\end{array}$ \\
\hline $\begin{array}{l}\text { Export: Machinery \& Equipment, Fabricated metal } \\
\text { products, Textiles\&Clothing, Transport equipmen. }\end{array}$
\end{tabular}

EXPO 2015 will be held in Milan, Italy; the GDP of 2013 and 2014 is showing positive trend and according to the main estimations it's above zero; Italy still remains a leading exporter of many good; the government has undertaken several reform initiatives in order to improve the current economic situation and to increase long-term economic growth; the new government with the new Prime Minister are elaborating new strategies, the program against corruption, taxation, innovation, program to reduce unemployment; one of Matteo Renzi's priorities will be to boost Italy's economic growth; in 2013 many Italian companies successfully went public. Europe's most successful initial public offering of 2013 was done by Moncler, the company's value increased significantly and so on [15].

When Italy recovers economic growth (for now the economic growth is much less than the interest rate that the country should pay for its debt) it will be able to pay not just interest rate of the debt but also the debt itself. Italy has a very good potential and together with other strategic programs of development this country can improve its position on the international market.

Italy's export volumes in 2013 remain almost the same compare with 2012, while imports decreased by $4.8 \%$. Export was positive towards non-EU countries $(+1.3 \%)$ and negative towards EU countries $(-1.2 \%)$ during the year 2013. Export as a percentage of GDP in 2012 was equal to $30 \%$, and Import 29\% [10]. The country's major trade partners are Germany, France, U.K., Spain, China, and the U.S. (table 6).

Ratings give the most complete picture of the economic development of Italy, for example,
Global Innovation Index, Global Competitiveness and Knowledge Economy Index.

1. The World Bank Report on Doing Business 2013, based on the criteria of the International Finance Corporation (IFC), ranked Italy 73th (76th in 2010, 80th 2011) in a list of 183 countries in terms of Doing Business. Several specific indicators had deteriorated, including building permits (103nd), starting a business (84th), access to credit (104th), protection of investors (49th) and enforcing contracts (160th), paying taxes (131th) [8]. The World Bank noted that high corporate taxes and excessive taxation of profits continued to be major problems and consequently ranked Italy 128 th[19].

2. According to the Global Innovation Index (GII) Italy ranks 29 out of 142 countries. Analyzing the report GII 2013 we can notice that at some position Italy ranks number 1 or in the first 20: ecological sustainability (rank 1), state of cluster development (rank 17), knowledge impact (14) etc. During 2008-2009 Italian rank was 31. Already at that time knowledge and cluster development were strong point of Italian characteristic [23].

3. Another important indicator that has to be taken into consideration is Global Competitiveness Index. According to the Global Competitiveness Report 2013-2014 Italy ranks 49, during 20122013 it ranks 42, during 2007-2008 it ranks 46. Analyzing the rank of Italy during the period 2007-2014 Italy has more or less the same position, even if the economy of Italy before crisis was stronger than nowadays. Relatively low Global Competitiveness Index helps to explain why Italian economy still didn't recover after the crisis [22]. 
4. Talking about Knowledge Economy Index (KEI) we can see that in 2012 Italy has the 30th position instead in 2008 it was 27 [26]. Many European countries have better performance in this field. KEI is estimated by World Bank as a 109 structural and qualitative variables for 146 countries to measure their performance on four Knowledge Economy pillars: Economic Incentive and Institutional Regime, Education, Innovation, and Information and Communications Technologies.

At the same time Italian economy hasn't recovered yet after the recession and World Financial crisis of 2008. It caused by the overall world situation which is not stable but not only. Italy has a set of problems and obstacles which keep Italian economy in stagnation and prevent the growth. Some of them are:

- the weak government and political apathy;

- the inefficient judicial system and gap between law and practice;

- the composition of trade changed significantly. This change was influenced by many external factors as cheap Chinese goods against expensive but high quality Italian one (on this base Italy lost its leading position in clothes and silk production); another example is furniture sector (high quality "handmade" Italian furniture against economically cheap Swedish Ikea);

- the high level of taxation: people prefer to find the illegal way to pay less tax;

- the high unemployment and specially youth unemployment;

- the unemployment among young people around $35 \%$.

The crisis gave many opportunities for those who wanted to buy Italian companies. Weakness of the euro and complicated banking system of Italy did not allow the firm to borrow money inside the country while trying to increase its equity. So many companies started looking for investments outside Italy (takeovers by French firms of Bulgari). Many Italian family-owned firms realised that, if they want to expand they must look for capital abroad. (For example, Italian world-leading family owned ceramic company Marazzi Group based on the decision of its owner was acquired by American company Mohawk Industries, Inc.) [15].

Italy's economy cannot be considered in the isolation from its peculiar properties. Based on the traditional approach they can be represented as follows:

- the economy is composed of many small and medium-sized family-owned companies;

- almost $70 \%$ of the Italian GDP is achieved in the service sector; tourism plays a very important role for the economy;
- mentality and traditions (south mentality, attitude to life and work is very different from the north part of the country).

The main peculiarities of Italian economy are so called "industrial districts" - special economic areas with certain characteristics. The study of the Italian economy through the prism of its districts the famous Russian scientist A.N. Pelyasov calls "the method of microscope" [32].

\section{Industrial districts: Italy's economy is "under the microscope"}

Italy is famous for its positive economic experience in the field of the "industrial districts". Among the processes of world transformation a special position have local systems as global players and initiators of global trends. As for the formal definition, it is given by the Italian Institute of Statistics: socio-economic unit on the local territory with the strong relationship between people and medium and small businesses involved in the same production. The most advanced results in the research of the current issue (in practice and in theory) refer to Italy that represented to the world the economic phenomenon of the "Third Italy" (the most famous region is Emilia-Romagna).

The practical experience of the "industrial districts" was successful. The Italian Institute of Statistics ISTAT defined 100 districts and assigns them special criteria (specialization in certain industries (textiles, furniture and ceramics, leather and footwear, agriculture); high concentration of small businesses in one area of the country; use of specific regional "know-how" and local resources $[4,28]$.

Italian economy is characterized by the developed north with many industrial companies and the less-developed (weak) south agriculture-based, with the high unemployment rate (the main indicator is the number of registered companies) (table 7).

Looking at the numbers you can see that South and Islands have bigger \% of the number of registered companies, there are two reasons for it, the first one is that geographically it has much bigger territorial extension and the second reason is that South and Islands are characterised by widespread micro-entrepreneurship. But if you look the \% of manufacturing companies you can see that they compose just $22.9 \%$ in South and Islands and 32.5 \% North-east. North-west together with Northeast give $54.8 \%$ of all manufacturing companies.

Industrial Districts contributed to the export of the country in 2013 with almost 80 billion euro, i.e. $20.5 \%$ (the total export of Italy 2013 was near 390 billion [11]. The trend of export by Industrial 
Registered Companies in Italy, the end of 2012 [4]

\begin{tabular}{|c|c|c|c|}
\hline & Total District's chain & Of which manufacturing & Core Business ${ }^{*}$ \\
\hline \multicolumn{4}{|c|}{ Absolute value } \\
\hline North-west & 38,724 & 38,470 & 40,495 \\
\hline North-east & 88,694 & 56,105 & 25,631 \\
\hline Centre & 40,991 & 38,714 & 57,487 \\
\hline South and Islands & 109,400 & 39,515 & 2,405 \\
\hline Italy & 277,809 & 172,804 & 126,018 \\
\hline \multicolumn{4}{|c|}{ Percentage value } \\
\hline North-west & 13.9 & 22.3 & 32.1 \\
\hline North-east & 31.9 & 32.5 & 20.3 \\
\hline Centre & 14.8 & 22.4 & 45.6 \\
\hline South and Islands & 39.4 & 22.9 & 1.9 \\
\hline Italy & 100.0 & 100.0 & 100.0 \\
\hline
\end{tabular}

* Core business - "traditional" sector (for example, furniture production in the district specializing in furniture production). Non core business - "support" sector of the traditional sector.

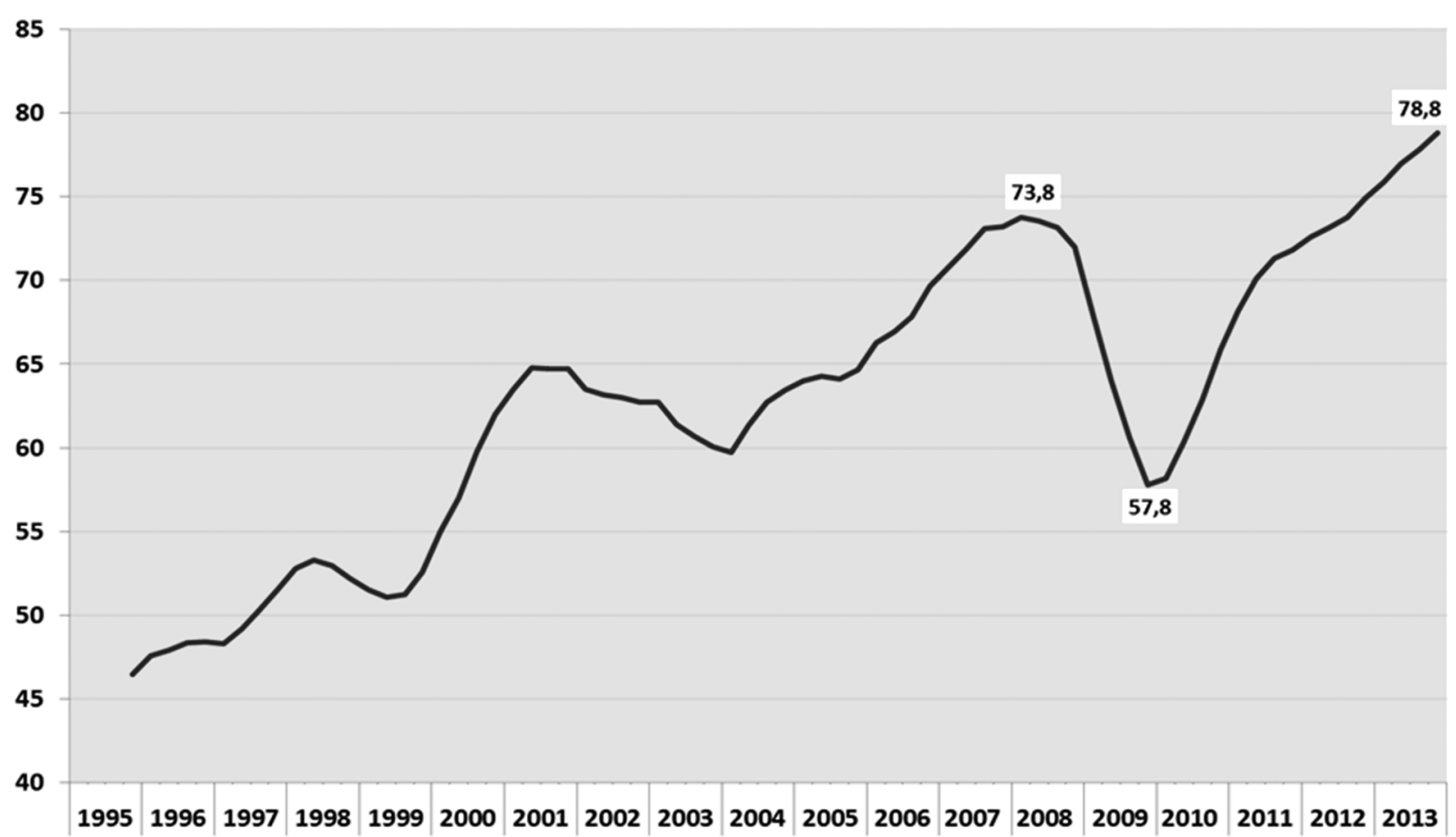

Fig. 1. Export of the 99 major Italian industrial districts: 1995-2013 [11] (billion euros at current prices)

Table 8

Districts is positive and during the last three years the growth was significant (fig. 1).

Analyzing the data in the table 8 we see that major export is done not only by Clothing and Fashion districts but by Automation - mechanical districts and the major growth show High - tech districts which we define as a point of knowledge.

At the national level the situation looks like this: first 5 regions compose $68.8 \%$ of all companies (table 9).

The future strategy goals of the traditional enterprises in industrial district (for example EmiliaRomania) are:
Export of the 99 major manufacturing districts by sector 2013 [12] (in millions of euro, \% change over the previous year)

\begin{tabular}{|l|c|c|}
\hline \multirow{2}{*}{} & \multicolumn{2}{|c|}{ Export of Districts } \\
\cline { 2 - 3 } & $\mathbf{2 0 1 3}$ & Var. \% \\
\hline Clothing and fashion (29 districts) & 27786,7 & 4.8 \\
\hline Home furnishing (14 districts) & 8428,3 & 3.2 \\
\hline $\begin{array}{l}\text { Automation-mechanical (32 } \\
\text { districts) }\end{array}$ & 22836,8 & 3.9 \\
\hline Food-wine (15 districts) & 6936,6 & 6.2 \\
\hline High-tech (9 districts) & 12814,9 & 9.4 \\
\hline TOTAL (99 districts) & 78803,3 & 5.2 \\
\hline
\end{tabular}


The number of registered companies in all Industrial District, the end of 2012 [4]

\begin{tabular}{|c|c|c|c|c|c|}
\hline Regional Ranking & Absolute values & $\begin{array}{l}\text { Percentage \% of } \\
\text { total number }\end{array}$ & Regional Ranking & Absolute values & $\begin{array}{c}\text { Percentage \% of } \\
\text { total number }\end{array}$ \\
\hline Veneto & 76,561 & 27.6 & Friuli V. G. & 7,022 & 2.5 \\
\hline Puglia & 63,042 & 22.7 & Marche & 6,145 & 2.2 \\
\hline Toscana & 29,573 & 10.6 & Lazio & 5,273 & 1.9 \\
\hline Lombardia & 22,025 & 7.9 & \multirow{2}{*}{ Emilia-Romania } & \multirow{2}{*}{4,715} & \multirow{2}{*}{1.7} \\
\hline Piemonte & 16,699 & 6.0 & & & \\
\hline Basilicata & 14,185 & 5.1 & Abruzzo & 2,571 & 0.9 \\
\hline Sicilia & 12,517 & 4.5 & Sardegna & 1,073 & 0.4 \\
\hline Campania & 12,432 & 4.5 & Trentino-A. A. & 396 & 0.1 \\
\hline
\end{tabular}

- the rationalization of costs and the efficiency of the offer of products through pricing policies;

- new investments in design and production diversification;

- the orientation in search for the new markets or new market niches with the purpose of internationalization;

- the greater control of distribution channels for products;

- investments in IT applications and information technologies.

But the future of Italy is defined by innovative industrial districts. Firstly, Veneto that specialized in Home System (Green building). The metadistrict is composed of both companies that produce eco-friendly materials and construction companies that use these eco-friendly materials and systems. The Green building market is entering today in a phase of strong growth. The production is carried out by operators in the district following macrosegments: professionals and related companies (design studios and architecture); companies operating in the construction sector buildings, residential buildings of new construction (single or two-family); companies that manufacture wood structures, installers, manufacturers of eco-friendly materials and production companies transverse to the different segments, such as "product providers": colors, paint, bricks, processors or other manufacturing sector [15]. Particularly relevant also the innovation aspect of environmental quality introduced in the conventional production processes.

The second place is confidently taken by District Aerospace of Puglia region (Province Puglia). Puglia boasts a historic presence in the aviation industry that dates back to 1934, when a group of wealthy Apulian founded the SACA to provide technical and logistical assistance to the airline ALA, in those years began connections with Greece and Turkey, with direct flights to Brindisi. The field of Puglia region specialization is aero- space, with particular reference to: production equipment and machined parts; heat treatment of aluminum and steel; components in composite materials, surface treatment and non-destructive testing; aircraft interiors; spatial components; steering and monitoring based on space technologies; planetary exploration; advanced sensory systems. In addition to this presence in Brindisi , already in the early 1970s Alenia in Foggia realized one establishment devoted to composite structures and also realized a few years ago, thanks to the contribution of the region, a new plant in Grottaglie, dedicated to large assemblies in composite for a new Boeing aircraft.

The aerospace cluster is a cluster of Puglia recognized by the Puglia Region. The core promotion of the district began to take its first steps in 2006 informally defining its strategy and initiating a gradual development activities and aggregation of the current members.

As a system the structure of the cluster is represented by the following elements:

- Group 1 - Large Enterprises (Alenia Aeronautica, Agusta Westland, Avio, SSI, Elsag Datamat, DEMA, TELCOM);

- Group 2 - Research Institutions (Public and Private ) (University of Salento, University of Bari, Polytechnic University of Bari, Aeneas, CNR, consortium Optel, consortium Cetma, Laser Center, Citadel Research);

- Group 3 - Institutions and Associations (Confindustria Puglia, AIAD (Aerospace and Defence Industries Association), Province of Brindisi, Municipality of Brindisi, C.I.S.L. Puglia, U.I.L. Puglia, C.G.I.L. Puglia);

- Group 4 - Small and medium-sized enterprises (SMEs).

The other example is the "Lecco Metalmechanical District" [27]. The district includes 28 municipalities of the province of Lecco, $7 \mathrm{mu}-$ nicipalities of the province of Como, 4 of that of Monza and Brianza, and one of the Bergamo, covering an area of $310 \mathrm{sq} \mathrm{km}$. The district is char- 
acterized by the strong inter-relations operating within the district, includes mostly small and medium size enterprises, so belonging to the District and the continuous exchange of know-how among the companies gives them indications to face the challenges of the market.

Except it the district is characterized by the following:

- the companies operating in the district have non- standardized and technologically less complex products, concentrating more on products with a higher added value;

- owners are created a "microteam" around himself, consisting of highly qualified personnel including the new generations of his own family;

- technicians to be employed are prepared by the Milan Polytechnic at Lecco where the Milan Polytechnic has established an autonomous Engineering faculty with a unique environment in which classroom training is strictly associated with hands-on experience within a company;

- unique public-private synergy experience: a typical example is represented by 'TecnoChora' reference point for problems concerning the technological implementation (Public "Sitec Lecco" together with "Lariodesk Informazioni" play a supportive role for innovation process in private sector);

- "ll-export" - the first export-orientated consortium established in Italy - has the task of promoting the "made in Lecco" on export markets; "Lariofiere" a qualified trade fair center, recognized as a reference point on a regional level through its exhibition "Altecnologie" Exhibition.

This strong network within one district from the innovative idea till the export of the finished product with the "Made in Lecco" label is a great example of how the inter-relations operat- ing and knowledge spillover can work. These districts can be characterized as a «localized knowledge spillover».

\section{Conclusion}

In conclusion, the functioning of the "industrial district" in the context of geo-economics and "knowledge spillovers" on the example of the theory and practice of Italian districts may be specified as the following:

- "industrial district" is one of the most important and interesting socio-economic phenomenon of recent decades, but the notion of a district should be rethought and modified;

- local structures perform higher rates of development, but they need to be of spatial development while preserving the identity;

- the core of the innovation process of the district is the search for knowledge;

- spatial development requires the active use of the new kind (non-material) of resources, which forms economical (not geographical or administrative) boundaries;

- characteristics typical for cluster indicators - "closeness, proximity" of localization - should be replaced by others, such as the branching network, data transmission rate, number of patents per capita, index of specialization of innovation, and others;

- information and innovation components must be added to the industrial aspect, as it significantly enhances the innovative orientation of the local structure of the industrial type;

- further research into the mechanisms of dissemination of knowledge from one district to another will allow harmonizing the economy of the country.

\section{References}

1. Alberti, F. (2001). The Governance of Industrial Districts: a Theoretical Footing Proposal. Liuc Papers, 82, Serie Piccola e Media Impresa, 5, gennaio. Available at: http://www.biblio.liuc.it/liucpap/pdf/82.pdf (date of access: 27.3.2014).

2. Becattini, G. \& Rullani, E. Local Systems and Global Markets. Available at: http://www.dse.unifi.it/becattini/frame.htm (date of access: 27.3.2014).

3. Becattini, G., Bellandi, M. \& Propris, L. (2010). Critical Nodes and Contemporary Reflections on Industrial Districts. Regional Responses and Global Shifts: actors, institutions and organizations. Regional studies association annual international conference. Available at: http://www.regional-studies-assoc.ac.uk/events/2010/may-pecs/papers/Becattini.pdf (date of access: 27.3.2014).

4. Club of Industrial Districts. Available at: http://www.urenio.org/2005/07/27/italian-industrial-districts/ (date of access: 27.3.2014).

5. Dataset GPD Ranking. Available at: http://data.worldbank.org/data-catalog/GDP-ranking-table (date of access: 27.3.2014].

6. Dataset from the Database of the World Bank. Available at: www.worldbank.org date of access: 27.3.2014).

7. Dataset from the Database of the International Monetary Fund. Available at: www.imf.org (date of access: 27.3.2014).

8. Doing Business in Italy 2013. Available at: http://www.doingbusiness.org/ (date of access: 27.3.2014).

9. Estimated GDP Growth rate. Available at: https://www.imf.org/external/pubs/ft/weo/2013/update/02/ (date of access: 27.3.2014).

10. Export and Import of Italy. Database of Eurostat. Available at: http://epp.eurostat.ec.europa.eu/ (date of access: 27.3.2014).

11. Export of Italian Regions. Availabl at: http://www.istat.it/en/archive/115078 (date of access: 27.3.2014).

12. Figura 2013. Available at: http://www.osservatoriodistretti.org/aggiornamenti (date of access: 27.3.2014).

13. Foreign Trade of Italy. Available at: www.istat.it (date of access: 27.3.2014). 
14. Frolova, Ye. A. (2013). Development of the Industrial Districts in the context of Globalization (Italian case). IY International conference Geography of WE. M.: RUDN, 338-343.

15. Frolova, Ye. A. (2014). The Competitiveness of Small Countries (Italian Case). Problems of Safe Development of Modern Society: Proceeding of the IV international scientific conference, 1. Yekaterinburg: UMC UPI, 57-65.

16. Frolova, Ye. D. \& Frolova, Ye. A. (2014). International Relations Analysis: Geoeconomical Approach. International Relations Analysis 2014: Methods and Models of Regional development. Proceeding of the V anniversary scientific conference. Katowice: University of Economics, 57-65.

17. Jean, C. \& Savona, P. (1997). Geoeconomics. Moscow: ANY, 207.

18. Investment Country Profile Italy. Available at: www.unctad.org (date of access: 27.3.2014).

19. Investment Climate Statement - 2012. Available at: http://www.state.gov/e/eb/rls/othr/ics/2012/191170.htm (date of access: 27.3.2014).

20. Inflation rate. Database of Eurostat. Available at: http://epp.eurostat.ec.europa.eu/ (date of access: 27.3.2014).

21. Italy in figures 2013. Report of Italian Institute of Statistic. Available at: www.istat.it (date of access: 27.3.2014).

22. Global Competitiveness Report 2007-2008, 2013-2014. Available at: http://www.weforum.org/reports/ (date of access: 27.6.2014).

23. Global Innovation Index (GII) 2013. Available at: http://www.globalinnovationindex.org/Reports (date of access: 27.6.2014).

24. GDP - Composition. Available at: https:/www.cia.gov/library/publications/the-world-factbook/geos/it.html (date of access: 27.3 .2014$)$.

25. GDP Growth Rate. Available at: http://data.worldbank.org/indicator/NY.GDP.MKTP.KD.ZG (date of access: 27.3.2014).

26. Knowledge Economy Index. Available at: http://www.worldbank.org (date of access: 27.6.2014).

27. Lecchese. Distretto metalmecanico. Available at: http://www.leccomech.com/ (date of access: 7.7.2014).

28. McDonald, F. Industrial Districts: State of the art review. McDonald F., Fiorenza Belussi, Susana Borras. Project West-East ID: Industrial districts re-location process: identifying policies in the perspective of the EU enlargement. Available at: http://westeast-id.tagliacarne.it/download/Deliverable.pdf (date of access: 27.3.2014).

29. Parmelee, M. (1949) Geoeconomic Regionalizm and World Federation. N.Y. : Exposition Press, 137.

30. Pilipenko, I. V. (2005) The competitiveness of nations and regions in the world economy. M.: Lomonosov Moscow State University, 496.

31. Population of Italy. Available at: http://data.worldbank.org/indicator/SP.POP.TOTL (date of access: 27.3.2014).

32. Pelyasov, A. N. (Ed.) (2012). Synergy in Space: regional innovation systems, clusters and knowledge spillovers. Smolensk: Oecumene, 760.

33. Somma, P. I distretti industriali: punti di forza e prospettive di sviluppo. Available at: http://www.pmi.it/economia/lavoro/ articolo/949/i-distretti-industriali-punti-di-forza-e-prospettive-di-sviluppo.html (date of access: 27.3.2014).

34. Tappi, D. The Neo-Marshallian Industrial District: A Study on Italian Contributions to Theory and Evidence. Max-Planck institute for research into economics Systems. Available at: http://www.druid.dk/conferences/winter2001/paper-winter/Paper/tappi. pdf (date of access: 27.3.2014).

35. Tatarkin, A. I. (2005). Socialno-economichesky status seredinnolgo regiona Rossii [Socio-economical Status of the Middle Russian Region]. Ekonomika Regiona [Economy of Region], 2, 5-23.

36. Unemployment rate. Available at: http://data.worldbank.org/indicator/SL.UEM.TOTL.ZS (date of access: 27.3.2014).

\section{Information about the authors}

Frolova Yelena Dmitrievna (Yekaterinburg, Russia) - Doctor of Economics, Professor, International Economy Department, Graduate School of Economics and Management, Ural Federal University named by the first President of Russia B. N. Yeltsin (office I-419, 19, Mira str., Yekaterinburg, 620002, Russia, e-mail: frol-uved@yandex.ru).

Frolova Yelena Alexandrovna (Milan, Italy) - Master of Management and Engineering, IT-consultant, Reply-consulting company (11, Via Castellanza, Milano, 20151, Italy, e-mail: e.frolova@reply.it). 